Indonesian Science Education Research

(ISER)

Available online https://jurnal.unimed.ac.id/2012/index.php/iser

ISSN Online: 2715-4653

\title{
MISCONCEPTIONS ON THE CONCEPT OF PHOTOSYTHESIS AND PLANT RESPIRATION FOR CLASS VIII AT SMP NEGERI 27 MEDAN IN SCIENCE LEARNING
}

Manurung G A, Simanjuntak L A, and Sihombing R A

Department of Science Education Universitas Negeri Medan graceangelinemanurung@mhs.unimed.ac.id

Accepted: October $12^{\text {th }}, 2021$. Published: December $31^{\text {th }}, 2021$

\begin{abstract}
This research aims to find out the misconceptions that occured in the concept of photosynthesis and plant respiration for Class VIII at SMP Negeri 27 Medan In Science Learning. The research method used by the writer in this research was descriptive qualitative method. The methodology itself was a process, principles, and procedures that use to approach problems and seek answers. The data collection technique was carried out through the technique of giving a modified google form questionnaire from a Denise journal questionnaire (2018) to several junior high school teachers in the city of Medan. Interviews were conducted to find out more in-depth things related to the misconceptions that occur in students on the concepts of photosynthesis and respiration. The results of the analysis of the misconception questionnaire and interview data by teacher and students in Class VIII at SMP Negeri 27 Medan were presented. Based on the results of the research and discussion, it can be concluded that the misconceptions of class VIII students at SMP Negeri 27 Medan fall into the "misconception" category with the criteria of "low" on the material of Photosynthesis and Plant Respiration.
\end{abstract}

Keywords: misconception, science learning, junior high school 


\section{Introduction}

Science education can be obtained through the learning process, namely the process of interaction between teachers and students. In this learning process, students are expected to understand the concepts being taught, not just memorize them. The ability of students to understand concepts is very important because concepts are the basis of thinking (Fandiyani, Jalmo \& Marpaung, 2017). Knowledge is not only transformed but also interpreted to produce new knowledge and students are trained to be able to think critically, think creatively, collaboratively and be able to communicate knowledge well (Yuliati, 2017).

One of the important goals of teaching is to help students understand the main concepts in a subject, rather than simply remembering isolated facts. If students' understanding of concepts is strong, students can develop and understand higher concepts, but often understanding concepts that are different from scientifically accepted concepts, resulting in misconceptions. In fact, one of the problems that is often found in science learning is that there are still many students who experience misconceptions (Siswana, Armen \& Hellenra, 2017). A misconception is categorized into five types namely preconceived notions, non-scientific beliefs of conceptual misunderstandings, conceptual misunderstandings, vernacular misconceptions, and factual misconceptions (Soeharto, et al. 2019). The teacher must improve the ability of creative thinking and critical thingking of students by directing students to solve problems that are more contextual and using research-based learning in learning process (Rahim, F. R., et al, 2019).

The condition of misconception if left unchecked will of course be dangerous considering that if this condition is allowed to persist, it will have an impact on the acceptance of the next concept. The misconceptions experienced by each student at school can be different with different causes. Therefore, it is very important for teachers to recognize misconceptions and their causes that occur in student (Yuliati, 2017).

This misconception problem is difficult to solve because the students' frame of mind is strong enough that it is difficult to change. If it is not resolved immediately, the misconceptions that students have will continue to persist until the next level of education may even persist until the student is an adult. The causes of misconceptions experienced by students can come from the students themselves, which are related to the initial knowledge possessed by students (preconceptions), stages of cognitive development that are not in accordance with the concepts being studied, students' reasoning is limited and wrong, students' ability to capture and understand concepts learned, and students' interest in learning the concepts being taught (Yuliati, 2017). Misconceptions may come from several sources, such as from teachers who deliver false concepts, from the students, and also from the lack of proper teaching methods. The causes for misconceptions happened are caused by the condition of students, teachers, textbooks, and context and teaching methods (Annisa, Yulinda \& Kartini, 2017).

Ariandini's previous research (2013) which identified misconceptions in junior high school students said that the concept of photosynthesis is one of the important concepts that has high difficulty so that conceptual misunderstandings tend to occur. Therefore, it needs to be identified so as not to cause learning problems in the future. Misconceptions must first be identified before they are corrected. Identification aims to distinguish students who understand concepts, misconceptions and do not understand concepts. Identification of misconceptions is needed in developing strategies to form correct knowledge in each student. Identification is very important in order to find misconceptions experienced by students. This is also supported by the study of Tekkaya (in Fandiyani, Jalmo \& Marpaung, 2017) which states that misconceptions are often experienced by students, namely in the matter of photosynthesis and plant respiration.

Selection of the right method in identifying misconceptions is very important. One way that can be done to find out students' misconceptions is to distinguish between understanding the concept and not knowing the concept. Teachers who know their students' most common misconceptions are more likely to increase their students' science knowledge than teachers who do not (Anjasari, 2018).

So that researchers want to find out how the misconceptions that occur in students, 
the authors conduct research by raising the title of the research, namely "Misconceptions The Concept Of Photosythesis And Plant Respiration For Class VIII At Smp Negeri 27 Medan In Science Learning".

\section{Research Method}

The research method used by the writer in this research is descriptive qualitative method. The methodology itself is a process, principles, and procedures that we use to approach problems and seek answers (Mulyana, 2008: 145). Another meaning of methodology according to Arina (2018), methodology is a formula in the application of research where in carrying out the research there are steps and also the results of the research. While the research methodology is a method or technique that is arranged regularly used by a researcher to collect data and information in conducting research that is tailored to the subject and object under study.

According to Arikunto's (2010) opinion, descriptive research is not intended to test certain hypotheses, but only describes what it is about a variable. According to Arikunto (2010) the qualitative research method is a display in the form of spoken or written words that are observed by researchers, and objects that are observed in detail so that the implied meaning in the document or object can be captured. So it can be concluded that qualitative descriptive research in this study is to see, review and describe in numbers about the object under study as it is and draw conclusions about it according to the phenomena that appear at the time the research was carried out.

This study uses two data collection techniques that are in accordance with the form of a qualitative research approach and the data sources used are the questionnaire method and the interview method.

\section{Questionnaire Method}

The data collection technique was carried out through the technique of giving a modified google form questionnaire from a Denise journal questionnaire (2018) to several junior high school teachers in the city of
Medan. Data is needed to complete the focus of this research in describing and analyzing various problems faced by teachers and students regarding the misconceptions of science learning in junior high schools in Medan.

\section{Interview Method}

Esterberg (in Sugiyono, 2009) defines an interview or interview as a meeting between two people to exchange information and ideas through question and answer, so that meaning can be constructed in a particular topic. The interview method in this study was an unstructured interview accompanied by several written tests. The interview guide that was carried out was only in the form of an outline of the problems that would be asked related to the results of the written test that had been done by the students. Interviews were conducted to find out more in-depth things related to the misconceptions that occur in students on the concepts of photosynthesis and respiration.

\section{Result and Discussion}

Result

The determine the category students' understanding level based on CRI and students' reasons for choice answer. Next analysis of student answers was carried out for distinguish between students who understand concept well, students who understand concepts but are not sure, students who misconceptions, and students who don't know draft. After that do the calculations the percentage of students to the four results assessment with the formula:

\section{$\mathbf{P}=\mathbf{f} / \mathbf{n} \times 100 \%$}

\section{Description:}

- $\mathrm{P}=$ group percentage number

- $\mathrm{f}=$ number of students in each group

- $\mathrm{N}=$ the number of individuals (the total number of students which is the subject of research)

The results of the analysis of the misconception questionnaire and interview data by teacher and students in Class VIII at SMP Negeri 27 Medan are presented in the following tables. 
Table 1. Concept and Questions Indicator

\begin{tabular}{|c|c|c|}
\hline Concept & Question Number & Question Indicator \\
\hline \multirow[t]{10}{*}{$\begin{array}{l}\text { Photosynthesis and Plant } \\
\text { Respiration }\end{array}$} & 1 & $\begin{array}{l}\text { Respiration in plants requires sunlight but animals } \\
\text { do not need it. }\end{array}$ \\
\hline & 2 & $\begin{array}{l}\text { Respiration in plants only occurs at night but all the } \\
\text { time for animals }\end{array}$ \\
\hline & 3 & $\begin{array}{l}\text { Respiration in animals produces energy but in plants } \\
\text { it does not. }\end{array}$ \\
\hline & 4 & Animals breathe but plants carry out photosynthesis. \\
\hline & 5 & $\begin{array}{l}\text { Plants absorb oxygen at night so they should be } \\
\text { placed outdoors. Meanwhile, during the day it } \\
\text { releases oxygen so it can be placed indoors because } \\
\text { it does not compete with other organisms for } \\
\text { oxygen. }\end{array}$ \\
\hline & 6 & $\begin{array}{l}\text { Respiration in plants requires chlorophyll but not in } \\
\text { animals. }\end{array}$ \\
\hline & 7 & $\begin{array}{l}\text { The parts of plant cells that can capture sunlight to } \\
\text { carry out photosynthesis are plastids }\end{array}$ \\
\hline & 8 & $\begin{array}{l}\text { The function of chlorophyll in the process of } \\
\text { photosynthesis is to absorb sunlight, especially } \\
\text { green light }\end{array}$ \\
\hline & 9 & $\begin{array}{l}\text { The characteristics of the light reactions in } \\
\text { photosynthesis are the conversion of light energy } \\
\text { into chemical energy }\end{array}$ \\
\hline & 10 & $\begin{array}{l}\text { In photosynthesis, oxygen is produced. The oxygen } \\
\text { released comes from the light and dark reactions in } \\
\text { photosynthesis }\end{array}$ \\
\hline $\begin{array}{l}\text { Recapitulation } \\
\text { percentage of grades un }\end{array}$ & $\begin{array}{l}\text { the averag } \\
\text { tanding of } \mathrm{a}\end{array}$ & \begin{tabular}{l|l}
$>2.5$ & $\begin{array}{l}\text { Don't know } \\
\text { the concept }\end{array}$ \\
\end{tabular} \\
\hline
\end{tabular}

students. And analyze students' misconceptions on the items with the highest percentage of students' misconceptions.

Table 2. Tier Category Modification Student Understanding

\begin{tabular}{|c|l|l|l|}
\hline Answer & Reason & $\begin{array}{l}\text { CR1 } \\
\text { Value }\end{array}$ & \multicolumn{1}{|c|}{ Description } \\
\hline Right & Right & $<2.5$ & $\begin{array}{l}\text { Understand } \\
\text { the concept } \\
\text { well }\end{array}$ \\
\hline Right & Right & $>2.5$ & $\begin{array}{l}\text { Understand } \\
\text { the concept } \\
\text { well but not } \\
\text { sure }\end{array}$ \\
\hline Right & Wrong & $<2.5$ & Misconception \\
\hline Right & Wrong & $<2.5$ & $\begin{array}{l}\text { Don't know } \\
\text { the concept }\end{array}$ \\
\hline Wrong & Right & $<2.5$ & Misconception \\
\hline Wrong & Right & $<2.5$ & $\begin{array}{l}\text { Don't know } \\
\text { the concept }\end{array}$ \\
\hline Wrong & Wrong & $>2.5$ & Misconception \\
\hline
\end{tabular}

Perform analysis of each student answers to distinguish from understanding the concept well, understand the concept but not sure misconceptions, and do not know the concept, with the following formula:

Table 3. Percentage Assessment Criteria Student's Level of Understanding

\begin{tabular}{|c|c|}
\hline Percentage & Category \\
\hline $0-20 \%$ & Very low \\
\hline $21-40 \%$ & Low \\
\hline $41-60 \%$ & Currently \\
\hline $61-80 \%$ & Tall \\
\hline $81-100 \%$ & Very high \\
\hline
\end{tabular}

Student questionnaire data analysis with score calculation using the following formula:

$\%=\mathbf{n} / \mathbf{N} \times 100 \%$

Description:

- $\%=$ Percentage of each question item

- $\mathrm{n}=$ Value of question items 
- $\mathrm{N}=$ Maximum value.

The results of this study were obtained based on questions results via google form using the CRI method and the results interview with some related student materials for photosynthesis and respiration in plants and misconceptions for teachers. Questionnaire results shows that misconceptions are only a few questions, the 10 questions given there are 8 questions that do not experience misconceptions and there are two questions that have misconceptions when doing quiz questions. However, students who answered the two questions turned out to be have understood the concept well after interview was conducted. The results can analyzed that there are two groups students according to the CRI method, these results includes students who know the concept (TK), Misconception (MK). The data can be written in Table 4 below:
Table 4. Percentage of Level of Understanding Student Class VIII-6 SMP Negeri 27 Medan

\begin{tabular}{|c|c|c|}
\hline \multirow{2}{*}{$\begin{array}{c}\text { Question } \\
\text { Points }\end{array}$} & \multicolumn{2}{|c|}{ Percentage (\%) } \\
\cline { 2 - 3 } & TK & MK \\
\hline 1 & 41,7 & 58,3 \\
\hline 2 & 50 & 50 \\
\hline 3 & 50 & 50 \\
\hline 4 & 16,7 & 83,3 \\
\hline 5 & 66,7 & 33,3 \\
\hline 6 & 25 & 75 \\
\hline 7 & 83,3 & 16,7 \\
\hline 8 & 75 & 25 \\
\hline 9 & 83,3 & 16,7 \\
\hline 10 & 75 & 25 \\
\hline Average & 56,67 & 43,33 \\
\hline
\end{tabular}

To see more clearly about the percentage level of understanding of grade VIII-6 students at SMP Negeri 27 Medan, see the bar chart below.

Figure 1. Bar Diagram of the Percentage of Increased Understanding of Students at SMP Negeri 27 Medan on Problem Numbers 1-5

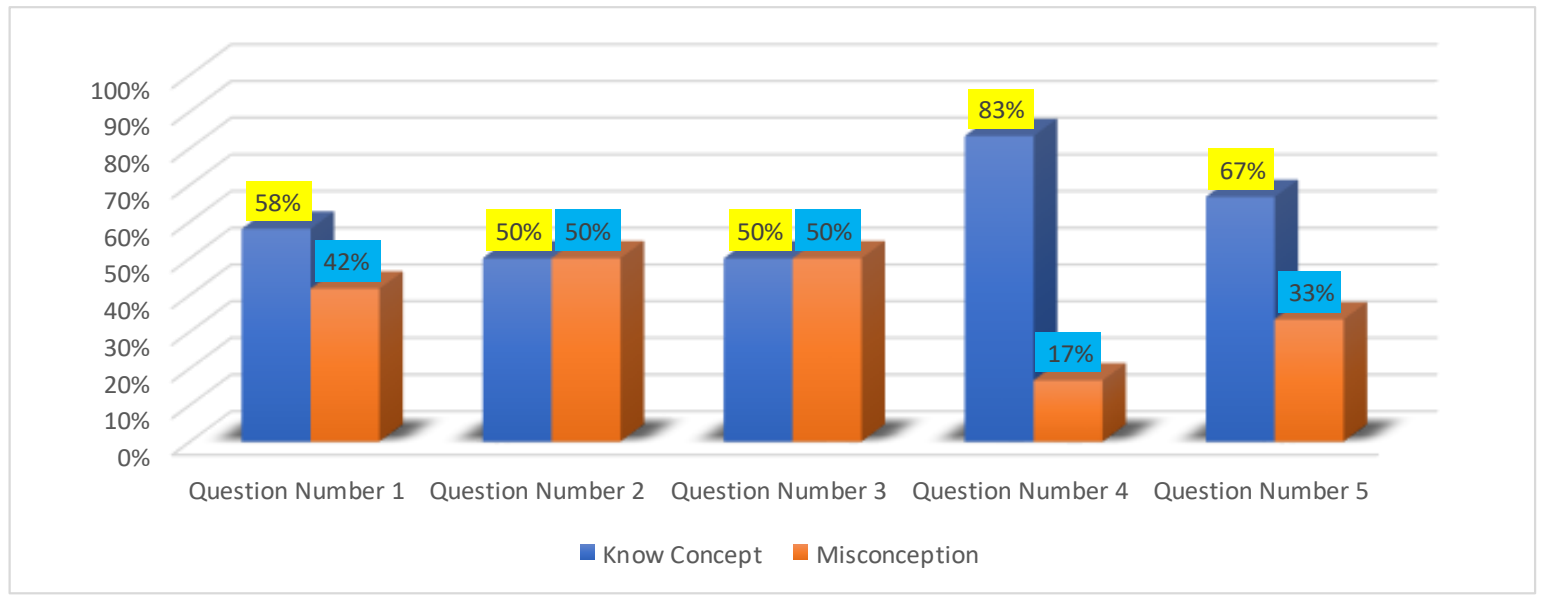

Figure 2. Bar Diagram of the Percentage of Increased Understanding of Students at SMP Negeri 27 Medan on Problem Numbers 6-10

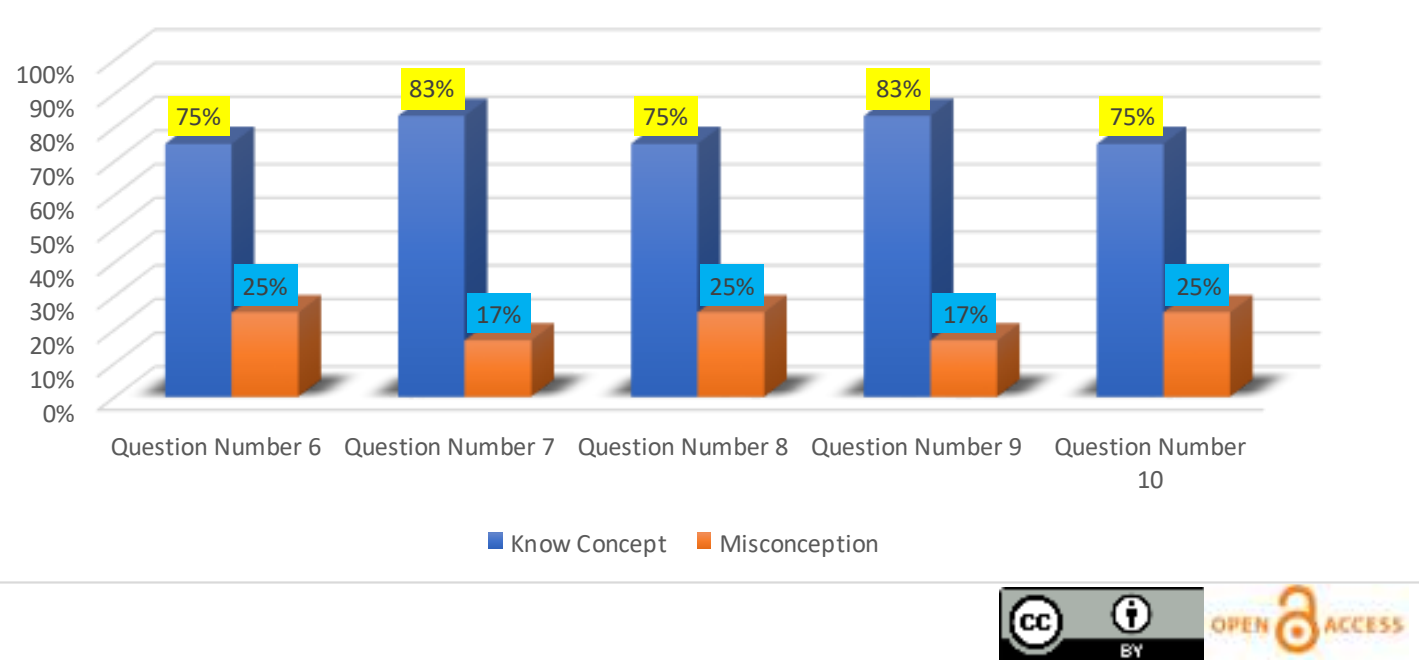


Before students learn science at school, students accidentally actually have a concept of science through their experiences in everyday life. The teacher's role is really very important in the process of building student knowledge, as a result, science learning is not just a process of transferring knowledge from teachers to students, but a meaningful learning process so that science content is well understood and can be applied by students enabling students to have a wrong understanding of a concept. Misunderstanding of the concept is called a misconception.

The results of the research on the analysis of student answers on the identification test at SMP Negeri 27 Medan in VIII-6 Class, it is known that students fall into the "Misconception" category with the criteria "Low" on the material of Photosynthesis and Plant Respiration. The results of this study were obtained based on the results of a quiz via google form using the CRI method and added by interviews with several students related to the materials of Photosynthesis and Respiration as well as direct observations of how teacher teaches in class. The quiz results showed that misconceptions almost did not occur in every question given, only 3 questions out of 10 questions experienced misconceptions, after we conducted interviews about 3 wrong questions, it turned out that overall they understood the concepts of photosynthesis and plant respiration.

Based on the research data that we obtained, students of class VIII-6 at SMP Negeri 27 Medan, on the material for the application of Photosynthesis and Plant Respiration, more or less all students experienced misconceptions and the location of the misconceptions experienced by students had similarities with other friends, namely first on the question First, Respiration in plants requires sunlight but animals do not need it. When we interviewed the students they all said that plants need light during respiration for photosynthesis while animals don't, even though like plants and humans, animals also need sunlight for their survival. Sunlight produces oxygen which is essential for animal survival. Then we explained to the students how animals need sunlight to carry out respiration. How to do it with the help of plants. Sunlight helps plants to photosynthesize. Well, photosynthesis is what produces oxygen, which animals and humans use for respiration.

Question Animals breathe but plants carry out photosynthesis. When interviewed about this question, on average, students said they were fooled by the question, where as we know plants are identical to photosynthesis, so they are often fooled that plants only carry out photosynthesis, even though plants are living things where the main characteristic is that they can breathe or carry out photosynthesis. respiration, it's just that the process of cellular respiration in plants has a complex process starting from the stage of glycolysis, the Krebs cycle, and electron transport which in the end produces energy in the form of ATP. The process of cellular respiration occurs in the mitochondria which have a function in the cell, namely as a producer of ATP. Unlike animals, the respiratory organs of one animal are not the same, depending on the type of animal. Breathing (respiration) is the event of inhaling air from the outside which contains (oxygen) and exhales air that contains a lot of carbon dioxide as a residue from oxidation out of the body.

Then the last question is Respiration in plants requires chlorophyll but not in animals. When we interviewed the students, they said they were fooled by the question where they only focused on chlorophyll, they said that they did not think that the question asked whether plants need chlorophyll to carry out respiration, then we interviewed the students, did they know what chlorophyll is and through whether plants do respiration, from these interviews they know what chlorophyll is the green substance in leaves, which gives the green color to leaves, while plants do respiration through stomata, this is proven by our question, namely the function of chlorophyll in the photosynthesis process is to absorb sunlight, especially green light. From these questions, students can answer and explain the reason correctly.

Misconception refers to a concept that is not in accordance with the scientific understanding accepted by experts. There are so many things that are factors that cause misconceptions experienced by students, 
including the preconceptions possessed by the students themselves, the teacher, the learning carried out by the teacher. From our observations, the science teachers who teach in class VIII at SMP Negeri 27 Medan are very good in teaching especially in providing concepts. In fact, learning is a process of interaction between students and educators and learning resources in a learning environment. In other words, learning is a process to help students learn well. Here the Science Subject Teacher Class VIII teaches the concepts of photosynthesis and plant respiration by relating them to everyday life, which makes students not only understand but train students in their reasoning. Besides that, the lessons were very fun, where ice breaking was done, and games related to the material of Photosynthesis and Plant Respiration. In addition, students are also invited to be active in learning and when we interviewed this was done so that learning about photosynthesis and respiration in plants went both ways. In addition, learning is carried out not only by the lecture method but surrounded by discussions and practicum, the teaching materials used are not only boss books from the government but also package books and the internet such as youtube and others.

In connection with the occurrence of misconceptions in students, constructivism experts view that students' knowledge is constructed or constructed by students themselves. The process of knowledge construction is not only logical thinking but is a mixture of experience, observations, thinking skills, and language skills. Therefore, the knowledge constructed by students may not be the same from one another. Moreover, when compared with the knowledge compiled by scientists. When students interact with their learning environment, students construct knowledge based on their experiences. Therefore, when the knowledge construction process occurs in students, it is very likely that errors will occur in the construction process because naturally students are not accustomed to constructing their own knowledge appropriately. Especially if it is not accompanied by clear and accurate sources of information.

\section{Conclusion}

Based on the results of the research and discussion above, it can be concluded that the misconceptions of class VIII students at SMP Negeri 27 Medan fall into the "Misconception" category with the criteria of "Low" on the material of Photosynthesis and Plant Respiration. The causes of misconceptions experienced by VIII students at SMP Negeri 27 Medan come from the students themselves, which are related to the initial knowledge possessed by students (preconceptions), the stage of cognitive development that is not in accordance with the concepts being studied, students' reasoning is limited and wrong, students' abilities capture and understand. But in terms of the teaching process carried out by the science teacher in class VIII at SMP Negeri 27 Medan which is classified as very good at teaching, especially in providing concepts. This misconception problem is not easy to solve. Based on these conditions, it is very important to do remediation by carrying out more challenging learning and inviting students to construct new knowledge through appropriate learning experiences. In addition, the technological and pedagogical abilities of teachers are also required to be able to present learning well. The ability of teachers to integrate various social media in learning will increase the meaning of learning (Hardinata A, et al, 2020).

\section{Reference}

Afidah, M., dan Nurkhasanah, L. 2019. Penggunaan Penalaran Pilihan Ganda Tes Untuk Menganalisis Miskonsepsi Pada Materi Fotosintesis Dan Respirasi Tanaman. Bio-Lectura: Jurnal Pendidikan Biologi, 6(1), 1-12.

Anjarsari, P. 2018. The Common Science Misconceptions in Indonesia Junior High School Students. Journal of Science Education Research, 2(1), 21-24.

Annisa, M., Yulinda, R., \& Kartini. 2017. Identifying The Misconceptions Of Natural Science (Ipa) Using Cri (Certanty Of Response Index) At The Primary School Students In Tarakan. Jurnal Ilmu Pendidikan Fisika, 2(2), 54-59.

Ariandini, D. et al. 2013. Identifikasi Miskonsepsi Siswa SMP pada Konsep Fotosintesis Melalui Analisis Gambar. FMIPA Universitas Pendidikan 
Indonesia.a

Arikunto, S. 2010. Metode peneltian. Jakarta: Rineka Cipta.

Arina, U. R. 2018. Makna Metodologi Penelitian. Universitas Muhammadiyah Sidoarjo.

Denise A. Schmidt., et al. 2018. Survey of Preservice Teachers' Knowledge of Teaching and Technology. Jurnal Ekonomi dan Pendidikan. Vol. 8(1):1935.

Devi Ariandini, et al. 2013. Identifikasi Miskonsepsi Siswa SMP pada Konsep Fotosintesis melalui Analisis Gambar. Jurnal Pengajaran MIPA, 18(2), 178184.

Fandiyani, K., Jalmo, T., \& Marpaung, R. R. 2017. The Identification of Students' misconception in the concept of photosynthesis and respiration of Plants. Jurnal Bioterdidik, 5(2), 1-9.

Hardinata, A., Simatupang, H., Hanifa, F., Latip, A., Efwinda, S., \& Yogica, R. (2020). SURVEY ON THE EFFECTIVENESS OF ONLINE LECTURES DURING COVID-19 PANDEMIC: METHODS AND DIFFICULTIES. ISER (Indonesian science education research), 2(2).

H. L. Lim and Y. P. Poo. 2021. Diagnostic Test To Assess Misconceptions On Photosynthesis And Plant Respiration: Is It Valid And Reliable? Jurnal Pendidikan IPA Indonesia, 10(2), 241-252.

Kartika Fandiyani, et al. 2017. Identifikasi Miskonsepsi Siswa Pada Konsep Fotosintesis Dan Respirasi Tumbuhan. Jurnal Bioterdidik, 5(2), 1-10.

Lasuen, U. O. (2016). Pre-Service Teacher Students' Misconceptions About Photosynthesis And Experimental Designs. Proceedings of ICERI2016 Conference (pp. 5601-5606). Seville: University of the Basque.

Mulyana, D. 2008. Metodologi Penelitian Kualitatif. Bandung: Remaja Rosda Karya.

Mustafa Urey. 2018. Defining the Relationship between the Perceptions and the Misconceptions about Photosynthesis Topic of the Preservice Science Teachers. European Journal of Educational Research, 7(4), 813 - 826.

Nining Hidayatun N W, et al. 2017. Identifikasi Miskonsepsi Siswa pada Materi Fotosintesis dan Respirasi
Tumbuhan. Jurnal Bioterdidik, 5(3), 110.

Puji Jayanti, et al. 2019. Comparative Study: Misconceptions On Photosynthesis And Respiration Concepts From Past To The Present. JPPS (Jurnal Penelitian Pendidikan Sains), 9(1), 1750-1755.

Siswana, R., Armen., \& Helendra. 2017. Identification Misconception Of Photosynthesis Material On Student Class IX SMP Negeri 7 Padang Using Diagnostic Test Two Tier Multiple Choice. Journal Biosains, 1(2), 277-284.

Soeharto, et a. 2019. A Review Of Students' Common Misconceptions In Science And Their Diagnostic Assessment Tools. Jurnal Pendidikan IPA Indonesia, 8(2), 247-266.

Sugiyono. 2009. Metode Penelitian Kuantitatif, Kualitatif dan R\&D. Bandung: Alfabeta.

Yuliati, Y. 2017. Miskonsepsi Siswa Pada Pembelajaran IPA Serta Remediasinya. Jurnal Bio Education, 2(2), 50-58.

Yunia, Ika., et al. 2019. Miskonsepsi Ipa Smp Pada Topik Fotosintesis Dan Respirasi. Seminar Nasional Pendidikan Sains 2019: Menyiapkan Guru IPA Masa Depan Menghadapi Transformasi Dunia Digital (pp. 1-4). Ngawi: STKIP Modern Ngawi. 